\title{
EM MEIO A CIDADÃOS E SOLDADOS: O MEIO TERMO POLICIAL NA REGÊNCIA DO IMPÉRIO
}

\author{
AMID CITIZENS AND SOLDIERS: THE POLICE MIDDLE GROUND \\ IN THE REGENCE OF EMPIRE
}

Joice de Souza Soares ${ }^{1}$

\begin{abstract}
RESUMO: O processo iniciado na década de 1820, com vistas a adequar o nascente Estado à primazia das leis e aos postulados constitucionais, também se vinculou à polícia. No início da Regência, anseios liberais que se colocavam desde anos anteriores conjugaram-se ao clima de instabilidade experimentado na Corte imperial, desencadeando modificações importantes no exercício das atividades policiais. Neste artigo, pretende-se demonstrar a relação entre os projetos políticos e as modificações nas instituições policiais, bem como sinalizar os limites do empreendimento liberal em tempos de turbulência política e social.
\end{abstract}

PALAVRAS-CHAVE: polícia; política; Estado; instituições; século XIX.

ABSTRACT: The process that began in the 1820s with a view to adapting the nascent State to the primacy of laws and constitutional postulates was also linked to the police. At the beginning of the Regency, liberal aspirations that had arisen since previous years were combined with the climate of instability experienced by the Imperial Court, triggering important changes in the exercise of police activities. This paper aims to demonstrate the relationship between political projects and changes in police institutions, as well as signaling the limits of liberal enterprise in times of political and social turmoil.

KEYWORDS: police; politics; state; institutions; XIX century.

\footnotetext{
* Este artigo é fruto da tese de doutorado intitulada "A polícia oitocentista entre a inovação e a tradição", defendida em fevereiro de 2019 sob a orientação da Profa. Dra. Icléia Thiesen.

${ }^{1}$ Bacharel e licenciada em História pela Universidade Federal do Estado do Rio de Janeiro (Unirio); mestre e doutora em História pela mesma instituição. joiceesoares@ hotmail.com
} 
Tempos de expectativas: anseios do pós-independência

O Brasil nascera enquanto Estado independente no início da década de 1820. E no período seguinte à emancipação, variadas disputas políticas se fizeram presentes. A implementação da monarquia constitucional colocava na ordem do dia aquelas em torno do que deveria ser, então, a Carta Magna.

Houvera, ao menos, quatro vertentes mais significativas: a primeira relacionada a um constitucionalismo histórico, em que os poderes dos legisladores já estariam inscritos na forma de governo vigente; a segunda relacionada ao entendimento da constituição enquanto conjunto de leis fundamentais, que estabeleceriam os direitos, as formas de governo da nação e as máximas gerais; a terceira vinculada à compreensão de que a constituição deveria ser um ato por meio do qual se determinariam as relações recíprocas do monarca com o povo; e a última, de caráter mais democrático, vinculada à compreensão de que a constituição não era um código ou um conjunto de leis, posto que tal instrumento pressuporia a existência de algo anterior. Nesse sentido, era necessário, a priori, a constituição do povo, de modo que todos os elementos do corpo político tivessem o exercício de seus direitos essenciais assegurados, antes da organização do código (NEVES; NEVES, 2008).

Não obstante, a despeito dos embates que resultaram na dissolução da Assembleia Constituinte, em novembro de 1823, as noções de que a Constituição do Brasil era um código, no qual estava estabelecido o pacto entre o monarca e os cidadãos, por meio do qual garantiam-se os direitos dos indivíduos e a limitação do poder do soberano, predominaram nos discursos posteriores à outorga de 1824 .

Àquela altura, o Império caminhava rumo à modernidade política (GUERRA, 1992, 2003). E, em tal cenário, sobretudo após o início das atividades da Assembleia Geral Legislativa em 1826, discussões aceca das transformações necessárias para a adequação das instituições oriundas dos 
tempos pré-constitucionais à primazia das leis ganhavam espaço no parlamento e fora dele ${ }^{2}$.

Posicionamentos favoráveis a criações e transformações institucionais davam a tônica dos discursos em meio a críticas sobre a organização da justiça e das instituições a ela relacionadas. À magistratura togada eram feitas censuras no tocante à ineficiência, corrupção e morosidade. E em relação à polícia não seria diferente.

A Intendência Geral da Polícia e sua Guarda Real - força militarizada subordinada tanto ao intendente quanto ao comandante de armas - foram estabelecidas no Rio de Janeiro no início do século XIX, após a chegada da Corte portuguesa, a exemplo de suas congêneres criadas em Portugal, a partir da segunda metade dos setecentos, vinculadas aos ideais da ilustração. ${ }^{3}$

Enquanto técnica e domínio intrínseco ao Estado, a polícia instituída no início dos oitocentos era responsável por inúmeros aspectos da vida dos indivíduos. No Rio de Janeiro, suas atividades se relacionavam também à civilização da antiga cidade colonial, vinculando-se a um projeto que colocava o Brasil como a parte mais importante do Império Ultramarino.

Cabiam às instituições policiais, nesse sentido, atribuições vinculadas à gestão do espaço urbano como a abertura de estradas, iluminação das ruas, controle de animais, autorização para funcionamento de estabelecimentos, limpeza e saúde públicas. Além disso, aspectos ligados a questões de foro íntimo pertenciam à sua alçada, cabendo à Intendência pacificar os conflitos por meio da assinatura de termos de bem viver e conciliação entre as partes.

\footnotetext{
${ }^{2}$ Todos os jornais citados neste artigo foram consultados por meio da Hemeroteca Digital da Biblioteca Nacional. Os dispositivos legais, infralegais e normativos foram consultados majoritariamente por meio da Coleção de Leis do Império do Brasil.

${ }^{3}$ Sobre a relação entre polícia e arte de governar na época moderna, ver: "A 'polícia' como síntese de ordem e bem-estar no moderno Estado centralizado", de Pierangelo Schiera (1984); "Aula de 29 de março de 1978" e 'Omnes et singulatim': uma crítica da razão política", de Michel Foucault $(2008,2012)$. Um panorama sobre as atividades da Intendência em Portugal pode ser encontrado em: "O direito de polícia nas vésperas do Estado liberal em Portugal", de José Subtil (2013); “A 'polícia' e as funções do Estado: notas sobre a 'polícia' do Antigo Regime" e "A polícia e o rei-legislador. Notas sobre algumas tendências da legislação portuguesa no Antigo Regime", de Airton Cerqueira-Leite Seelaender $(2009,2010)$. Destacase, ainda, a obra de Laurinda Abreu (2013) sobre a instituição em finais do século XVIII, intitulada "Pina Manique: um reformador no Portugal das Luzes".
} 
A perseguição aos desertores das tropas militares e a vigilância dos espaços públicos também integravam o rol de atribuições das instituições policiais. ${ }^{4}$ E, por certo, o domínio sobre a população negra, escravizada e liberta, se vinculava à manutenção da ordem nas ruas. ${ }^{5}$

O intendente, magistrado à frente da instituição policial, detinha amplos poderes, dentre os quais o de liberdade e o de soltura no tocante a inúmeros delitos. O arbítrio figurava não como uma exceção, mas como condição comum ao exercício da atividade policial nos tempos da Intendência.

No tocante à punição de alguns crimes, conforme alvará de 1780, não havia a obrigatoriedade de processo como condição prévia à pena, ficando o intendente responsável pelo julgamento e punição dos indivíduos, podendo assim “[...] prender aquelas pessoas, que a merecerem [correção], conservandoas na prisão o tempo que julgar proporcionado à desordem que tiverem cometido e lhe parecer necessário para emenda".

Com o advento do Estado monárquico-constitucional, todavia, a limitação do poder estatal em distintas esferas se apresentava como questão prioritária. Nos discursos, as atividades da polícia eram tratadas como espionárias e despóticas - incompatíveis, por princípios, com os postulados caros ao liberalismo político.

Nas páginas dos jornais de tendência liberal, redatores e correspondentes asseguravam a necessidade premente de extinção da polícia tal qual estava estabelecida. As justificativas, além do flagrante antagonismo em

\footnotetext{
${ }^{4}$ Sobre as áreas de atuação da Intendência Geral no início do século XIX, ver: "A IntendênciaGeral da Polícia: 1808-1821", de Maria Beatriz Nizza da Silva (1986); "A Intendência de Polícia e a civilização do Rio de Janeiro", de Vinícius Cranek Gagliardo (2004); e "Um Império nos Trópicos: a atuação do Intendente Geral de Polícia, Paulo Fernandes Viana, no Império Luso-Brasileiro", de Nathália Gama Lemos (2012). Sobre as atividades desempenhadas por sua Guarda Real, ver: "Guarda Real da Polícia do Rio de Janeiro: um estudo sobre as atribuições da primeira instituição policial ostensiva brasileira (1809-1831)”, de André Luís Cardoso Azoubel Zulli (2018).

${ }^{5}$ A presença da escravidão fora um diferencial significativo entre as experiências lusa e brasileira. Sobre as relações entre polícia e escravidão no início do século XIX, ver: "O feitor ausente: Estudos sobre a escravidão urbana no Rio de Janeiro (1808-1822)", de Leila Mezan Algranti (1988); "Entre dois cativeiros: escravidão urbana e sistema prisional no Rio de Janeiro 1790-1821", de Carlos Eduardo M. de Araújo (online); e "O Calabouço e o Aljube no Rio de Janeiro no século XIX", de Thomas Holloway (online).
} 
relação ao sistema constitucional, se vinculavam a inúmeras denúncias de abusos, violências e desvios de conduta dos agentes policiais.

Ao passo que os apelos para a supressão das instituições policiais se apresentavam, incluindo aqueles direcionados à Guarda Real e ao "espírito militar", ${ }^{6}$ considerado elemento típico do Antigo Regime e associado ao despotismo, soluções nos moldes liberais se faziam presentes. ${ }^{7} \mathrm{Em}$ fins da década de 1820, seriam aprovados dois dispositivos vinculados a esse processo: as leis de 15 de outubro de 1827 e de $1^{\circ}$ de outubro de 1828 .

A primeira regulamentava - e ampliava - as atribuições dos juízes de paz, magistrados eleitos localmente, previstos na Constituição de 1824 apenas como conciliadores na fase preliminar dos processos. ${ }^{8}$ A segunda reformulava as Câmaras Municipais - instâncias tradicionais de decisão de outrora -, esvaziando-as de seu poder político, mas conferindo-lhe amplas atividades em matéria administrativa - entre elas, a elaboração das posturas policiais, que diziam respeito às atividades da Intendência vinculadas à gestão dos espaços públicos.

Nos anos seguintes às determinações legislativas, o desarranjo entre as autoridades responsáveis pelas atividades policiais ganhava espaço nas páginas dos periódicos. Isso porque, mesmo com os juízes de paz e a reformulação das instituições municipais, a Intendência Geral e sua Guarda Real mantinham-se em atividade, o que causava exasperação a inúmeros liberais do período.

A solução da questão - ou ao menos parte dela - só viria na década de 1830, após a abdicação do primeiro monarca e a instalação do governo regencial. Àquela altura, o terreno encontrava-se fértil para a implementação de projetos presentes nos discursos, proferidos no parlamento e nas folhas dos jornais, desde meados da década anterior.

\footnotetext{
${ }^{6}$ A Aurora Fluminense, n. 59, de 25 de junho de 1828, p. 243.

${ }^{7}$ Sobre as críticas em relação às instituições policiais estabelecidas no início do século XIX e as expectativas de transformação institucional nos moldes liberais, ver: "Polícia e Juízes de Paz na imprensa oitocentista (1826-1829)", de Joice de Souza Soares (2017).

${ }^{8}$ Sobre a magistratura de paz no Império, ver a clássica obra "El juez de paz y el jurado en el Brasil imperial”, de Thomas Flory (1986); "As seduções da ordem: violência, criminalidade e administração da justiça, Minas Gerais, século 19", de Ivan de Andrade Vellasco (2004); e "Juízes de Paz, mobilização e interiorização da política", de Adriana P. Campos e Ivan de Andrade Vellasco (2011).
} 
Não obstante, em um cenário de franca instabilidade política e social, as modificações não seriam fáceis. As determinações do Executivo e do Legislativo no início da Regência demonstravam os limites da inovação perante a tradição. E as disputas em torno das transformações institucionais revelavam as inúmeras mesclas entre o antigo e o moderno realizadas nesse processo.

Interregno liberal: a reformulação policial da teoria à prática

Ainda antes da abdicação de Pedro I, conflitos entre lusitanos e brasileiros se tornaram frequentes, tendo destaque nas noites de março de 1831 - quando das emblemáticas garrafadas.

Naquele momento, nas páginas dos periódicos de tendência liberal e antagonistas ao governo do imperador, os discursos alinhavam as ações empreendidas pela Intendência Geral da Polícia e pela Guarda Real ao "partido recolonizador". As acusações se vinculavam, nesse sentido, à instrumentalização das instituições policiais por parte dos portugueses em oposição aos brasileiros. Em edição datada de 16 de março de 1831, lia-se na Aurora Fluminense:

[...] na ocasião da gloriosa batalha, o teatro da guerra foi coberto de tropas, cujo serviço único foi o de tirarem quaisquer armas, ou paus, àqueles indivíduos que pareciam Brasileiros, deixando aliás os que do outro lado andassem em grandes magotes correndo as ruas, praticando impunemente toda a espécie de violências. Se estas foram as ordens que os militares, especialmente a Polícia, haviam recebido, não o sabemos, mas afirmam-nos que sim, e os fatos suficientemente o demonstram. ${ }^{9}$

Quando liberais moderados assumiram o controle do governo após a abdicação, ainda sob a Regência provisória, contavam com maioria no parlamento - notadamente na Câmara dos Deputados; estava aberto, então, o caminho para modificações institucionais em diferentes frentes, inclusive para aquelas relacionadas ao policiamento das ruas e à administração da justiça.

\footnotetext{
${ }^{9}$ A Aurora Fluminense, n. 462, de 16 de março de 1831, p. 1950.
} 
Embora a designação dos grupos ou facções tenha assumido um caráter generalista e até mesmo um tom pejorativo, conforme atribuído pelos próprios contemporâneos, havia projetos políticos relacionados a cada um deles.

Liberais moderados tinham como objetivo primordial a realização de transformações políticas e institucionais com vistas à garantia dos direitos previstos constitucionalmente, sobretudo os de cidadania, defendendo uma concepção de liberdade que não ameaçasse a ordem imperial.

Por seu turno, liberais exaltados partilhavam de concepções mais radicais do liberalismo, pregando reformas políticas e sociais mais drásticas, como a implementação de uma república federativa, a ampliação dos direitos de cidadania civil e política e o fim gradual da escravidão.

Por fim, caramurus partilhavam uma visão conservadora acerca dos postulados liberais, colocando-se contrariamente às reformas institucionais, notadamente a da Constituição, e advogavam em prol de uma monarquia constitucional forte e centralizada, nos moldes do Primeiro Reinado. ${ }^{10}$

O clima de instabilidade que tomara as ruas da Corte no início da década de 1830 fora, decerto, ingrediente de suma importância para as tomadas de decisão naquele período. Em edição datada de 13 de abril, Evaristo da Veiga transcrevia nas páginas da Aurora Fluminense a "Ordem do dia" expedida pelo comandante de armas da Corte, José Joaquim de Lima e Silva - irmão do regente, ainda provisório naquele momento, Francisco de Lima e Silva.

A determinação da maior autoridade militar da Corte se dirigia aos " [...] honrados Cidadãos, que tão briosamente se apresentaram no Campo da Honra para defender as liberdades Pátrias", e determinava que todos os que decidissem sair do acampamento, por quaisquer motivos, deveriam se despojar das armas das quais dispusessem - particulares ou "nacionais" -, entregando-as às autoridades ali presentes.

\footnotetext{
${ }^{10}$ Sobre os grupos políticos e seus projetos em finais do Primeiro Reinado e na Regência, ver: “O império em construção: projetos de Brasil e ação política na Corte Regencial”, de Marcello Basile (2004); e "As transformações dos espaços públicos: imprensa, atores políticos e sociabilidades na cidade imperial (1820-1840)", de Marco Morel (2005).
} 
A decisão autorizava as patrulhas a "[...] desarmarem os infratores desta ordem, que unicamente tem por fim a manutenção da boa ordem, sem o que não pode haver verdadeira liberdade". A resolução do comandante afirmava, ainda, que o cidadão desejoso de representar sobre qualquer assunto deveria fazê-lo de forma individual e por escrito ao juiz de paz da paróquia, presente no campo. ${ }^{11}$

A preocupação de José Joaquim de Lima e Silva não parecia ser exagerada. Nas páginas da Aurora Fluminense, em edição de 30 de maio, tratava-se dos rumores acerca de um plano para derrubar a Regência; ademais, os boatos também estavam vinculados ao antilusitanismo, na medida em que se postulava a expulsão de portugueses.

Após os acontecimentos de março, a abdicação de Pedro I e a chegada dos moderados ao poder criaram muitas expectativas a respeito da punição dos lusitanos envolvidos nos confrontos das garrafadas. A reticência do governo regencial em fazê-lo e, além disso, uma espécie de silenciamento em torno da permanência de portugueses em postos da administração despertavam a ira da oposição exaltada.

Em edição datada de 28 de abril, Borges da Fonseca, redator de O Repúblico, pedia providências ao Judiciário, afirmando que a demora no julgamento dos portugueses presos pelos acontecimentos de março acirrava os ânimos e era prejudicial ao Brasil. Segundo o redator, “[...] da impaciência do povo se tem sabido aproveitar alguns velhacos, e perturbadores, que, iludindo aos de boa-fé, querem que se conserve o povo em estado revolucionário". ${ }^{12}$

Por sua vez, os relatos sobre crimes eram constantes. No início de junho, sob a pena do redator e deputado moderado Evaristo da Veiga, afirmava-se que assassinatos, ferimentos e roubos teriam ocorrido nos dias anteriores, como o caso do contador do tesouro público, João José Rodrigues Vareiro, que fora morto com uma punhalada. Asseverava que os "[...] perversos se derramam pelas ruas, aproveitam o estado de estupor em que se acha a população, de

\footnotetext{
${ }_{11}^{11}$ A Aurora Fluminense, n. 471, de 13 de abril de 1831, p. 1984.

${ }^{12}$ O Repúblico, n. 59, de 28 de abril de 1831, p. 277.
} 
contínuo ameaçada com desordens, motins e rusgas, e praticam, mal que vem às sombras da noite, toda casta de violências". ${ }^{13}$

Em meio à tamanha efervescência política e social, a Corte do Império parecia um barril de pólvora. E, nas páginas dos jornais, medidas eram requeridas às autoridades com vistas a restabelecer a ordem pública. Quando a Câmara Municipal do Rio de Janeiro fizera uma proclamação aos "[...] briosos concidadãos fluminenses”, em virtude dos “[...] gloriosos acontecimentos políticos dos sempre memoráveis dias 6 e 7 de abril”, Evaristo da Veiga ressaltava, em seu jornal, que mais importante que proclamar era agir. Segundo sua perspectiva, “[...] em revolução, a primeira necessidade é operar ativamente, dar providências prontas, para que o mal se atalhe a princípio, antes de criar maiores forças". ${ }^{14}$

Ainda sob a Regência provisória, algumas medidas seriam tomadas. Em 4 de junho, o então ministro Manoel José de Souza França, que ocupava as pastas da Justiça e do Império, declararia que os juízes de paz estavam autorizados a executar as novas posturas municipais - tão solicitadas nas páginas da Aurora. Dois dias depois, José Manoel de Moraes, titular do Ministério da Guerra, mandara publicar disposições acerca dos ajuntamentos ilícitos e do uso de armas fora do serviço militar - o risco de sublevação das tropas era flagrante.

As decisões dos dias 8 e 11 de junho iam no mesmo sentido. Via Ministério da Justiça, o governo censurava duramente a Câmara Municipal no tocante às medidas para iluminação da cidade - ou melhor, pela falta delas. No documento do dia 8 , advertia-se a instituição municipal sobre o péssimo serviço prestado aos cidadãos da cidade e afirmava-se ser “[...] mister corrigir com a justa severidade que merece tão culpável falta de cumprimento dos seus deveres". Alguns dias depois, em outra determinação, ordenava-se que todos os marinheiros encontrados em terra após o pôr do sol fossem remetidos ao juiz de

\footnotetext{
${ }^{13}$ A Aurora Fluminense, n. 492, de 3 de junho de 1831, p. 2080.

${ }^{14}$ A Aurora Fluminense, n. 491, de 1 de junho de 1831, p. 2076.
} 
paz competente para impor-lhes as penas previstas nas posturas da Câmara Municipal.

O Legislativo também fizera sua parte. Em 6 de junho fora promulgada a lei que dava "[...] providências para a pronta administração da justiça e punição dos criminosos". O novo dispositivo legal tinha como função principal ajustar as penas do Código Criminal, aprovado no ano anterior - e que já era considerado deveras brando - às circunstâncias conflituosas de 1831 .

Não havia transcorrido um ano da promulgação do Código Criminal, e lia-se na Aurora Fluminense postura, de fato, deveras distinta daquela adotada em fins do ano de 1830, quando se encontrava em discussão o projeto do referido código:

[...]Não somos ávido[sic] de castigos, mas a justiça é a conservadora dos Estados, e o Código penal que hoje temos, se peca, não é de certo por nímia severidade. O maior inconveniente que oferece, é antes a doçura das penas, pouco proporcionadas com o estado de civilização do nosso povo".

Pela lei de 6 de junho, estabelecia-se, em primeiro lugar, que os compreendidos no crime de "ajuntamento ilícito" - previsto no artigo 285 do Código Criminal - seriam punidos com três a nove meses de prisão. Era, sem dúvida, um endurecimento da previsão aprovada em 1830, haja vista que os artigos 286, 287 e 288 da lei de 1830 - que estabeleciam as penas para o crime - não previam tal punição. Ademais, ficava proibido qualquer ajuntamento noturno, de cinco ou mais pessoas em ruas, praças e estradas, “[...] sem algum fim justo, e reconhecido"; a penalidade seria de um a três meses de reclusão.

Ademais, ficava estabelecido que toda pessoa considerada suspeita por alguma circunstância, de dia ou de noite, seria observada pelas rondas, a fim de identificar se portava armas. Em caso positivo, seria levada à autoridade competente. Por seu turno, os presos em flagrante nos crimes policiais - aqueles compreendidos entre os artigos 275 e 307 do Código Criminal - não teriam direito à fiança.

\footnotetext{
${ }^{15}$ A Aurora Fluminense, n. 513a, de 1 de agosto de 1831, p. 2175.
} 
No que tange à organização das atividades policiais, a mudança significativa viera por meio da ampliação das atribuições dos magistrados eletivos. Aos juízes de paz fora conferida competência para punir todos os crimes de polícia, com autoridade cumulativa em todo o munícipio - pela lei de $1^{\circ}$ de outubro de 1828 , cabia-lhes, apenas, função privativa no julgamento das infrações cometidas às posturas da Câmara Municipal. Poderiam, ainda, nomear delegados e oficiais de justiça nos seus distritos. A Intendência Geral da Polícia continuava a existir, mas suas atribuições policiais passaram a ser exercidas em conjunto com os juízes eleitos.

O dispositivo legal também autorizava o governo a alistar e armar cidadãos, desde que preenchida a condição de eleitores, para auxiliar os juízes de paz em suas atividades - fornecendo-lhes armamento e munição. Os membros de tais guardas cidadãs estavam sujeitos, em caso de abusos “[...] das armas ou do emprego honroso que se lhe confia", às penas previstas na legislação; e, caso cometessem infrações desse tipo, ficariam inabilitados para o serviço por três anos.

Poucos dias depois seria promulgado o decreto que criava em cada distrito de paz um corpo de guardas municipais dividido em esquadras. As esquadras deveriam ser compostas de 25 a 50 cidadãos, conforme as determinações constitucionais para serem eleitores. Cada corpo deveria possuir um comandante geral, ao qual eram subordinados os comandantes das esquadras. O alistamento, a divisão de esquadras e a nomeação de comandantes - tanto de esquadras quanto gerais - eram da alçada dos juízes de paz.

Efetivamente, ao criar as guardas municipais, o governo regencial inaugurava uma nova forma de patrulhamento da cidade: realizada por civis os cidadãos eleitores, sob o comando de autoridades de mesmo caráter; e, notadamente, estabelecidas por eleição - os juízes de paz.

Nas páginas dos periódicos, os discursos em prol do estabelecimento de "guardas cidadãs" apareceria há algum tempo. Ainda nos idos de abril, na Aurora Fluminense era possível encontrar uma espécie de representação da Câmara Municipal de São Paulo, dirigida a Diogo Antônio Feijó, acerca de tal 
necessidade. No documento, os vereadores daquela cidade lembravam ao então parlamentar

[...] a urgente necessidade de instituir-se, e organizar-se, quanto antes Guardas Nacionais, que defendendo o sistema jurado, afiancem nossa Liberdade, e nos livrem de convulsões políticas que possam comprometer nossa segurança, e bem ser. ${ }^{16}$

Em edição datada de 30 de maio, o redator da Aurora informava aos leitores que uma comissão fora instituída, no âmbito da Câmara dos Deputados, para elaborar o projeto de criação das Guardas Nacionais ${ }^{17}$. Afirmava que essa e outras medidas - uma delas a lei de 6 de junho - sairiam da Assembleia Geral.

Outrossim, caberia ao governo regencial empregar "[...] todos os meios à sua disposição para conter os excessos criminosos, que podem ser prelúdio de mil desastres, se não atalham a princípio". Convocava os cidadãos, mesmo antes da promulgação do decreto de 14 de junho, a

[...] prestarem-se prontos ao chamado dos Juízes de paz a fim de rondarem em seus respectivos distritos. Se não quiserem fazer agora algum sacrifício, talvez ao depois seja tarde, e que lastimem em vão a sua incúria e desleixo. Cumpre que nos unamos todos quantos queremos a ordem, a lei e a liberdade, para defendermos sob o mando das autoridades legítimas nossas propriedades e vidas, que não se defendem, fechando-se cada cidadão timidamente em sua casa, senão comparecendo todos à voz dos magistrados, e fazendo causa comum para esse fim. ${ }^{18}$

Ao passo que avançava o projeto de instituição das Guardas Nacionais, cuja lei seria promulgada em agosto daquele ano, caminhava-se para a redução das forças das tropas tradicionais. Em edição de 11 de julho daquele ano, lia-se no jornal de Evaristo da Veiga, principal representante dos moderados na

\footnotetext{
${ }^{16}$ A Aurora Fluminense, n. 473, n. 18 de abril de 1831, p. 1995.

${ }^{17}$ Não cabe nos limites deste artigo uma análise aprofundada acerca da Guarda Nacional. As relações entre a Guarda e as instituições policiais serão apresentadas na medida em que se relacionem com os projetos políticos em curso, e em disputa, no início da década de 1830 para a polícia. Sobre a Guarda Nacional, ver o clássico trabalho de Jeanne Berrance de Castro (1977), intitulado "A milícia cidadã: a Guarda Nacional de 1831 a 1850"; e ainda "Os oficiais do povo: a Guarda Nacional em Minas Gerais oitocentista, 1831-1850)" e "O império da ordem: Guarda Nacional, coronéis e burocratas em Minas Gerais na segunda metade do século XIX (18501873)", de Flávio Henrique Dias Saldanha (2006, 2013).

${ }^{18}$ A Aurora Fluminense, n. 490, de 30 de maio de 1831, p. 2072.
} 
imprensa da Corte, sobre as discussões ocorridas na Câmara para a fixação das forças militares.

Os deputados decidiram por " $[\ldots] 10$ mil homens entre oficiais inferiores e soldados, além dos pedestres; ficando desde já abolidos os corpos da polícia”. Por sua vez, no mesmo número, o redator informava ter recebido "[...] diversas correspondências, insistindo sobre a brevidade da conclusão da Lei que cria as Guardas Nacionais". Naquele momento, o projeto tramitava no Senado; e, sob a lógica presente nas folhas da Aurora, "[...] quaisquer emendas que se possam agora fazer-lhe, não equivalem ao prejuízo da demora, e que só a experiência nos poderá ilustrar sobre os inconvenientes práticos que haja de oferecer". ${ }^{19}$

As medidas empreendidas tanto pela Regência quanto pela Assembleia tinham como objetivo solucionar a "anarquia" em que se encontravam as ruas da Corte e, sobretudo, impedir que tal panorama se repetisse nas províncias. Entretanto, cumpre compreender que o projeto encetado pelos moderados, quando no poder, tentou conciliar anseios vindos dos anos anteriores com as circunstâncias que se colocavam.

Desde fins da década de 1820, o "espírito militar" era criticado nas páginas dos jornais liberais. Por um lado, os governadores de armas enviados às províncias eram censurados por atitudes consideradas despóticas; por outro, a contratação de tropas estrangeiras fora alvo de desaprovação constante ao longo do Primeiro Reinado.

A caserna tinha grande preponderância na administração de Pedro I e, portanto, era alvo de desconfianças. Ademais, com a sublevação "do povo e da tropa" no concurso da "revolução" do 7 de abril, bem como com as dificuldades para controlar as forças nos dias que se seguiram, os receios aumentaram basta notar as ordens expedidas por José Joaquim de Lima e Silva na Corte.

Por sua vez, no que se relaciona às instituições policiais, inúmeros discursos contrários à Intendência Geral e à sua Guarda Real foram tecidos na imprensa periódica. Criadas sob o Antigo Regime, consideradas como resíduos

\footnotetext{
${ }^{19}$ A Aurora Fluminense, n. 506, de 11 de julho de 1831, p. 2136-2137.
} 
da tirania em tempos constitucionais, ambas as instituições foram alvo de censuras.

Pari passu, fazia-se a defesa das instituições liberais e constitucionais, notadamente da magistratura eletiva, como solução ao problema policial. Destarte, a ampliação das atribuições dos juízes de paz para além de sua previsão constitucional já havia sido intentada desde os anos de 1827 e 1828; mas ainda não restava consolidada sua condição, ao menos como igual, perante as autoridades policiais de outrora.

A solução moderada fora, então, a de conferir amplos poderes aos magistrados eletivos - já em 1831, dando continuidade ao processo iniciado na década anterior e que seria encerrado com a aprovação do Código de Processo Criminal, no ano seguinte. Desta vez, suas pretensões encontrariam êxito. Do mesmo modo, em meio a suspeitas em relação às forças militares - que, de certo modo, se relacionavam também a um princípio básico liberal de desconfiança do poder (BASILE, 2009) - lançaram mão do recurso que dispunham: o medo dos cidadãos perante a possibilidade de perderem suas vidas e propriedades.

$\mathrm{O}$ estabelecimento das guardas municipais, enquanto medida temporária, e das Guardas Nacionais - a posteriori - se inscrevia, ainda, numa lógica liberal que àquela altura estaria presente no imaginário político dos coevos: partia-se da premissa de que a participação dos cidadãos nas instâncias de decisão, considerando que eram tais indivíduos aqueles que efetivamente poderiam se beneficiar com a boa prática institucional, conduziria ao aperfeiçoamento e melhoramento das instituições - e, por conseguinte, do Estado. ${ }^{20}$ Era a mesma crença que legitimava a participação cidadã nos juizados de paz e no tribunal do júri. ${ }^{21}$

\footnotetext{
${ }^{20}$ Sobre o tema, ver: "Visconde do Uruguai: centralização e federalismo no Brasil", de Ivo Coser (2008).

${ }^{21}$ Havia uma perspectiva de alargamento da participação dos cidadãos nas instituições que remontava à década anterior. Mas era sempre matizada. As instruções fornecidas pelos periódicos quando das eleições para as localidades - vereadores e juízes de paz demonstravam isso. A defesa era a de uma ampliação da participação dos indivíduos, mas que garantisse a prevalência dos "homens bons" nas instituições. Na mescla entre o antigo e o moderno, tal lógica se convertera na necessidade de garantir que apenas os eleitores e os
} 
É possível que as ruas da cidade tenham experimentado alguns dias de tranquilidade após o estabelecimento das guardas municipais - que duraria pouco, a bem da verdade. Em 25 de junho, uma decisão do ministro da justiça tornava evidente que o estabelecimento dos "paisanos" gerara ainda mais "rusgas". Dirigindo-se ao juiz de paz da freguesia de Santa Anna, Souza França asseverava ter recebido dois ofícios do ministro da marinha datados de 21 e 23 daquele mês, por meio dos quais teria se inteirado das "novidades" ocorridas entre as rondas municipais naquele distrito e o $2^{\circ}$ tenente da armada, Gervásio Mancebo, nas noites dos 17 e 21.

Conforme estabelecido na determinação ministerial, o referido tenente fora detido por uma das rondas daquele distrito, que o considerara suspeito em virtude da "[...] frequência com que divagava de noite pela rua Formosa da Cidade Nova, ocorrendo a circunstância de ali mesmo ter feito uma desordem poucos dias antes e ser conhecido por homem rixoso e de caráter violento". No entanto, outro oficial militar retirara Gervásio do poder da ronda que o prendera.

A ordem expedida pelo ministro lançava luz sobre a lógica que estruturaria o sistema policial da Corte nos anos seguintes. O Código de Processo Criminal estabeleceria a obrigatoriedade de os juízes de paz noticiarem os acontecimentos de seus distritos, a partir das informações levantadas pelos inspetores de quarteirão, ao chefe de polícia - que, por sua vez, deveria reportá-las ao ocupante da pasta ministerial da justiça.

Todavia, nos idos de 1831, a decisão estabelecia outro ponto importante, que não pode ser negligenciado no contexto de crise daquele ano. Conforme o ministro,

[...] os militares nenhum privilégio têm que os isente de serem presos em flagrante por qualquer cidadão; antes, esse procedimento se acha mui expressa e terminantemente

\footnotetext{
"cidadãos proprietários" participassem do processo. De fato, o critério de renda não seria deveras alto e possibilitaria a presença de indivíduos das camadas médias da população. Ressalta-se, no entanto, a permanência da lógica de diferenciação entre os grupos sociais elemento estruturante daquela sociedade, estabelecida sob o regime escravista. Tais mecanismos de distinção remetiam à organização social dos tempos coloniais, que não fora sobremaneira alterada com o advento do Estado monárquico-constitucional.
} 
autorizado pelo Alvará com força de lei, de 21 de outubro de 1763 , nos parágrafos $\S \S 6^{\circ}$ e $7^{\circ}$; deve Vm., porém, proibir que as rondas apalpem, não só aos Oficiais Militares, como a quaisquer pessoas conhecidas, que pelo seu caráter pacífico, não são suspeitas à tranquilidade pública, bastando por isso que qualquer dos cidadãos que compõem a ronda conheça o indivíduo, pois que sem prejuízo do serviço se pode muito bem observar esta atenção. ${ }^{22}$

Em primeiro lugar, Souza França abolia - em tese - a regalia de membros das forças militares, sobretudo oficiais, perante às guardas cidadãs. ${ }^{23}$ No entanto, abria espaço para a discricionariedade nas ações, na medida em que vinculava a critérios subjetivos a definição dos indivíduos sobre os quais as ações das guardas iriam se impor. Em um ambiente com manifesta fragilidade política, bem como marcado por profunda desigualdade social, tal abertura ao arbítrio significava, grosso modo, o estabelecimento - explícito ou velado - de categorias "suspeitas" sobre as quais a ação dos "paisanos" se faria presente.

Do estabelecimento da medida ministerial até o fatídico 14 de julho, poucos dias haviam passado. A animosidade entre militares - tanto das tropas regulares, quanto dos membros da Guarda Real da Polícia - e os integrantes das guardas municipais aumentava. E as medidas do governo em relação às tropas, que desempenharam papel de suma importância na "revolução" de abril, acirravam os ânimos.

Em 12 de julho, o $26^{\circ}$ Batalhão de Infantaria se amotinou - era uma das unidades a ser dissolvida. Acredita-se que não por coincidência, já que fora a mesma tropa mencionada por Ezequiel Corrêa dos Santos, redator da Nova Luz Brasileira, quando se referira aos acontecimentos das "garrafadas". Teriam sido os membros desse "respeitável" corpo os que se indignaram contra a proteção que a polícia, liderada pelo comandante Frias, dava aos portugueses. ${ }^{24}$

\footnotetext{
${ }^{22}$ N. 152 - Justiça - em 25 de junho de 1831 - Os militares nenhum privilégio têm que os isente de serem presos em flagrante por qualquer cidadão. .

${ }^{23}$ Poucos meses depois, em setembro daquele ano, um conflito que tomaria grandes proporções na cidade se iniciara justamente porque um oficial militar teria se recusado a permanecer sob a tutela de uma autoridade civil nas dependências do teatro da cidade. Sobre o assunto, ver: "Revolta e cidadania na Corte regencial", de Marcello Basile (2007).

${ }^{24}$ Nova Luz Brasileira, n. 129, de 25 de março de 1831, p. 600.
} 
As guardas municipais foram acionadas e cerca de seiscentos civis estiveram armados no entorno do mosteiro de São Bento. A rápida ação do governo, somada à promessa de não retaliar os envolvidos caso aceitassem a remoção da unidade para fora da capital, fez com que as tropas aquiescessem. Entretanto, o clima ainda era de tensão. Ao dividir a unidade insubordinada, enquanto acertava os detalhes de sua transferência para a Bahia, o governo utilizou, na noite do dia 13, alguns de seus membros na vigilância de partes da cidade (HOLLOWAY, 1997).

Pelas ruas da Corte, soldados do $26^{\circ}$ batalhão entraram em contato com as tropas da Guarda Real da Polícia, que exerciam suas funções regulares de patrulhamento. Acendia-se o pavio - a explosão viria no dia seguinte. Ao passo que navios deixavam a cidade, carregando os amotinados do dia 12 , os soldados da Guarda Real marchavam pelas ruas - e os relatos davam conta de que o caos tomara a cidade (HOLLOWAY, 1997).

Engrossavam as fileiras revoltosas rumo ao Campo do Santana - à época, da Honra - inúmeros civis, sobretudo aqueles de "ínfima condição" aos quais Evaristo da Veiga se referira. As demandas diziam respeito à recomposição do $26^{\circ}$ batalhão e ao fim dos castigos físicos para os militares (HOLLWAY, 1997) - tema, aliás, explorado pela imprensa exaltada há tempos. Três meses depois da "revolução gloriosa", povo e tropa estavam novamente nas ruas.

Com a cidade em polvorosa, as primeiras medidas começariam a aparecer. No dia 16, o ministro da guerra - Manoel da Fonseca Lima e Silva expedira três decisões relacionadas às demandas dos revoltosos militares. A primeira dizia respeito à permissão para que os soldados pudessem servir “" [...] nos corpos estacionados nas Províncias de suas naturalidades, ou naquelas de mais proximidade, onde se designam paradas". A determinação tinha como objetivo "[...] aliar o bem do serviço com a comodidade das praças".

A segunda determinava que fossem demitidos do serviço os soldados violentamente recrutados, "[...] tais como filhos únicos de viúvas, homens casados que deixaram em abandono suas famílias". Estabelecia, ainda, que 
houvesse "[...] escrupulosa indagação" acerca de tais arbitrariedades. A última, por fim, estipulava o fim do "[...] aviltante castigo das chibatadas".

No dia seguinte, por seu turno, era a vez de uma lei e um decreto serem promulgados - a primeira extinguiu a Guarda Real; o segundo conferiu ao governo a prerrogativa de nomear um comandante geral para as guardas municipais, centralizando a administração das "guardas cidadãs".

Em relação à primeira determinação, cumpre ressaltar um aspecto. Ainda que as críticas às instituições policiais tenham sido uma constante durante toda a década de 1820, parece que a oposição ao governo de D. Pedro I, notadamente aquela presente na Câmara dos Deputados, não tivera forças para levar a cabo suas intenções quando o Estado ainda se encontrava sob a égide do monarca.

A lei de 24 de novembro de 1830 determinou o efetivo das forças de terra para o ano financeiro de 1831-1832. Conforme o dispositivo legal, os corpos de polícia existentes àquela época deveriam ser "[...] conservados em seu estado completo, sendo as companhias de cavalaria substituídas por outras de infantaria, se assim o julgar conveniente”. Ou seja, a despeito das críticas à Guarda Real, a instituição estava mantida, tal como existia, para os anos de 1831 e 1832.

Quando a Assembleia Geral iniciara seus trabalhos em maio de 1831, o cenário político era em verdade distinto. E o tema da extinção da força policial viera à baila. De fato, um dia antes de o $26^{\circ}$ batalhão se rebelar, em 11 de julho, o periódico redigido por Evaristo da Veiga fazia menção à abolição dos corpos policiais no âmbito das discussões parlamentares. ${ }^{25}$ Nesse sentido, mais do que uma consequência do motim ${ }^{26}$, a extinção da Guarda Real era a implementação - ainda que urgente naquele contexto, dada a sublevação das tropas - dos

\footnotetext{
${ }^{25}$ A Aurora Fluminense, n. 506, de 11 de julho de 1831, p. 2136.

26 Tal perspectiva é a adotada por Holloway (1997) quando trata dos acontecimentos relacionados ao motim policial e militar de 1831. Para o autor, a abolição da Guarda Real da Polícia e a redução das forças militares vieram a reboque, como consequência, da sedição militar. No entanto, considerando os debates apresentados na imprensa, postula-se que, em verdade, o projeto político moderado tinha como meta tais ações, antes mesmo da eclosão da revolta de julho daquele ano.
} 
postulados liberais moderados aventados desde a década anterior; e que só teriam encontrado possibilidade de efetivação no período após a abdicação.

Em relação às guardas municipais, o decreto de 17 de julho trazia algumas alterações significativas. O dispositivo de 14 de junho daquele ano concebera as atividades das referidas guardas de forma descentralizada, ao nível de cada um dos distritos de paz. Os comandantes gerais eram nomeados pelos magistrados eleitos das respectivas localidades e a eles estavam subordinados. A determinação de julho, por seu modo, criava um cargo que o decreto não estabelecera previamente - e que, de fato, parece não ter sido concebido ou idealizado a princípio -, centralizando a organização das guardas.

$\mathrm{O}$ primeiro artigo do decreto de julho autorizava o governo a “[...] nomear um Comandante Geral das guardas municipais desta cidade, cujo exercício dure até que cessem as presentes circunstâncias". Além disso, a excepcionalidade da medida se fazia ver pela ampliação nos critérios estabelecidos para o alistamento: seriam aceitos os filhos de pessoas que atendessem aos critérios para serem eleitores, desde que maiores de 16 anos e “[...] que sejam reputados idôneos pelos respectivos juízes de paz”. Um alargamento, por certo, que mantinha a lógica da diferenciação.

As ações de contenção, por assim dizer, terminariam com a criação, por meio de decisão do ministro da guerra, no mesmo dia, de um corpo de oficiais que deveriam agir voluntariamente "[...] para guarnecer algumas repartições e estabelecimentos públicos". O objetivo era proteger pontos importantes da cidade, como o tesouro público e o arsenal do exército, dos "[...] inimigos da ordem".

A partir de então, as ruas passaram a ser patrulhadas por membros das guardas municipais e do corpo dos oficiais soldados, cujo efetivo crescia significativamente. Com o passar dos dias, a cidade voltaria a contar com relativa tranquilidade. Os civis envolvidos no levante cansavam-se do espetáculo e as tropas insurgentes deixavam, pouco a pouco, as fileiras rebeldes; a repressão, por certo, surgira efeito. 
Mas os meses finais de 1831 não reservaram boas novas para o governo. As páginas dos jornais continuariam a noticiar perturbações, conflitos e crimes. Para além das questões relacionadas às disputas políticas entre as facções, o ano de 1831 fora marcado pelo risco da sublevação popular. As narrativas dos diferentes conflitos ocorridos nas ruas da cidade apresentavam sempre a presença de indivíduos das camadas sociais mais baixas, de diferentes cores, entre os quais certamente havia inúmeros escravizados.

Além de garantir que a "nau do Estado" caminhasse pelo caminho do liberalismo moderado - em verdade, exatamente por isso -, colocava-se flagrante para o grupo que conduzia o governo e se apresentava como maioria no Legislativo a necessidade de assegurar a ordem nas ruas - o que significava garantir o controle da "populaça".

Considerando a desconfiança de moderados em relação aos militares, que remontava à década anterior, e, sobretudo, a impossibilidade de contar com tropas que quase sempre estavam envolvidas nos conflitos, a solução encontrada fora a de conferir a segurança e a defesa da propriedade àqueles que tinham interesse em sua salvaguarda. A menção à paralisação do comércio e aos entraves que tais distúrbios causavam à indústria eram constantes.

Ressentindo-se pela forma como o redator da Nova Luz se referia aos guardas municipais, associando-os aos portugueses envolvidos nos conflitos de março, descrevendo-os como inimigos dos brasileiros e capazes de atrocidades, ${ }^{27} \mathrm{o}$ redator da Aurora saía em defesa da recém-criada instituição.

Para Evaristo Ferreira da Veiga, os "vândalos de fardeta e boné" conforme a perspectiva estabelecida nas páginas da Nova Luz - eram, na verdade, a “[...] massa respeitável de cidadãos, armados para a manutenção da ordem pública". À crítica de que seriam os membros da "guarda cidadã" os portugueses implicados nas garrafadas, respondia da seguinte forma:

[...] e quem são os Guardas municipais? São todos os membros da associação Brasileira, todos os cidadãos que por qualquer modo lícito fazem mais de $200 \$$ réis de renda anual. No Rio de Janeiro, aonde a N. Luz se publica e a que especialmente se referem aquelas palavras, raro é o artista, o

\footnotetext{
${ }^{27}$ Nova Luz Brasileira, n. 176, de 29 de setembro de 1831, p. 965.
} 
jornaleiro livre que não recebe dois cruzados diários, os quais no ano, descontados os dias santos e domingos, excedem o cômputo dos $200 \$$ réis exigido para pertencer das guardas municipais. ${ }^{28}$

Com efeito, o redator da Aurora fora um apologista fiel da participação cidadã nas instituições policiais. Nos idos de 1820, posicionava-se veementemente a favor da magistratura de paz em substituição às autoridades policiais existentes; no início da década seguinte, estabelecia com afinco a necessidade de que os cidadãos se engajassem nos serviços das guardas. A despeito disso, suas posições davam indícios daquilo que seria uma das marcas fundamentais do liberalismo moderado nos anos iniciais da Regência: a defesa de instituições sob os moldes liberais - conjugadas a práticas autoritárias.

Não obstante o enaltecimento das guardas municipais e de suas ações fossem frequentes sob a perspectiva moderada, os conflitos compunham sobremaneira a realidade da cidade do Rio de Janeiro nos idos de 1831. Com a dissolução das forças militares - do exército e da polícia - a maior parte das atividades de policiamento ficara a cargo das "guardas cidadãs". De fato, após o motim de julho daquele ano, a menção à polícia enquanto força de segurança praticamente não era encontrada nos periódicos.

A despeito disso, alguns problemas em relação à organização das guardas se colocavam. Para além das rivalidades entre os "paisanos" e os militares - que causaram tantos tumultos na cidade -, havia mais. Nas páginas do periódico moderado, asseverava-se que "[...] outro inconveniente que se tem notado é a má vontade ou a moleza que certas pessoas têm mostrado neste interessante serviço". ${ }^{29}$

A questão apresentava, ainda, outra dimensão. Os guardas municipais eram cidadãos alistados como eleitores e, por conseguinte, com exigência de renda mínima para sua atuação. Nas palavras de Evaristo da Veiga, somente “[...] os vadios, os vagabundos, os mendigos, os sicários do cacete e punhal”,30

\footnotetext{
${ }^{28}$ A Aurora Fluminense, n. 540, de 7 de outubro de 1831, p. 2290.

${ }^{29}$ A Aurora Fluminense, n. 521, de 24 de agosto de 1831, p. 2214.

${ }^{30}$ A Aurora Fluminense, n. 540, de 7 de outubro de 1831, p. 2290.
} 
estariam excluídos das guardas. No limite, isso significava reconhecer que seus membros desempenhavam outras atividades laborais.

Ora, a partir dessa perspectiva, torna-se compreensível conceber os motivos pelos quais inúmeros cidadãos, ainda que interessados na manutenção da ordem pública, escusavam-se do serviço. Nas páginas da Aurora, esse aspecto fora alvo de atenção por parte do redator. No início de outubro, lia-se no periódico que "[...] a fadiga de um serviço continuado para homens que durante o dia vivem da sua indústria, atenua as forças, e cansa os espíritos". 31

Em meio à premente necessidade de garantir a ordem nas ruas - mas repelindo a alternativa de confiar o policiamento da cidade às tropas do exército - e às dificuldades com o efetivo das guardas municipais, a solução moderada viria pelo juste-milieu: o Corpo de Guardas Municipais Permanentes.

Em outubro de 1831, com tom crítico sobre uma determinação expedida pela pasta ministerial da guerra, em que se chamavam de outras partes da província à Corte quinhentos milicianos, Evaristo afirmava: “[...] Opor-nosemos com todas as nossas débeis forças a que se faça ressuscitar no Brasil esse espírito guerreiro de procissão que o ex-Imperador procurou aclimatar no nosso país[...]".32

Assim, após os incidentes de 14 julho, o ministro da justiça autorizara no mesmo mês a organização de um " [...] corpo de tropa regular para auxiliar a polícia" - aquele criticado por Ezequiel Corrêa dos Santos quando da abolição da Guarda Real. ${ }^{33}$ Segundo consta da decisão ministerial, o referido corpo seria formado por trinta soldados de cavalaria, três cabos e um furriel; o comando, sob a responsabilidade do tenente-coronel Francisco Theobaldo, seguia a lógica militar.

Com o desenrolar dos acontecimentos daquele ano, postula-se que a ideia se desenvolveu de modo a conciliar o princípio dos cidadãos em armas à existência de um corpo militarmente organizado. Nas páginas da Aurora,

\footnotetext{
${ }^{31}$ A Aurora Fluminense, n. 538, de 3 de outubro de 1831, p. 2283.

${ }^{32}$ A Aurora Fluminense, n. 545, de 19 de outubro de 1831, p. 2312.

${ }^{33}$ Nova Luz Brasileira, n. 169, de 10 de setembro de 1831, p. 914.
} 
Evaristo apresentara a ideia do "[...] Corpo municipal a soldo", posto que, segundo sua perspectiva,

[...] a verdadeira bravura achar-se-á sempre como em um cofre, no coração do homem livre, e que ama a pátria; a ciência da guerra nos oficiais militares que por sua aplicação e estudo forem dignos de tal nome; no momento do perigo, milhares de cidadãos aparecerão sob as armas, dirigidos por esses chefes inteligentes, e saberão sujeitar-se à disciplina dos combates, sem perderem o amor da liberdade, e o nobre sentimento da independência individual. ${ }^{34}$

Em 10 de outubro fora promulgada a lei que autorizava a criação de corpos de guardas municipais voluntários na Corte e nas províncias. O objetivo dos corpos era "[...] manter a tranquilidade pública, e auxiliar a Justiça". No entanto, havia algumas modificações significativas em relação às guardas municipais estabelecidas em junho, modificadas em julho - e extintas, via de regra, pela lei que criara a Guarda Nacional.

$\mathrm{Na}$ Corte, o parlamento autorizava o governo a criar as referidas guardas; nas províncias, tal prerrogativa caberia ao presidente em conselho. ${ }^{35}$ Ademais, os municipais voluntários receberiam "[...] vencimentos estipulados”. E, por fim, todas as questões relacionadas às guardas municipais como organização, pagamento dos seus membros, nomeação e despedida dos comandantes, instruções para desempenho das atividades e boa disciplina remontavam ao governo.

Poucos dias depois, a Regência baixou um decreto regulamentando o Corpo de Guardas Municipais Permanentes na Corte. Para auxiliar nas ações da

\footnotetext{
${ }^{34}$ A Aurora Fluminense, n. 545, de 19 de outubro de 1831, p. 2312.

${ }^{35} \mathrm{O}$ Conselho Geral da Provínicia, previsto constitucionalmente, se vinculava à garantia de todo cidadão interferir nos negócios de sua região. Deveria ser instalado em todas as províncias do Império, menos naquela em que estivesse localizada a capital. Nas provínicias populosas, o Conselho deveria possuir 21 membros; nas demais, 13. Todos eleitos do mesmo modo e na mesma ocasião em que fossem eleitos os representantes da nação, pelo tempo da legislatura. Com competência limitada para propor e deliberar, suas resoluções deveriam ser encaminhadas ao Executivo imperial por meio do presidente da provínicia, cuja nomeação era prerrogativa do imperador. Se a Assembleia Geral estivesse em sessão, suas deliberações deveriam ser remetidas ao parlamento pela respectiva Secretaria de Estado para serem apreciadas como projetos de lei. A lei de 27 de agosto de 1828 estabelecera as regras de seu funcionamento e ainda lhe concedara atribuições apenas delineadas pela Carta Magna de 1824. Sobre o tema, ver: "Sob o império das leis: Constituição e unidade nacional na formação do Brasil (18221834)", especialmente o segundo capítulo, de Andrea Slemian (2006).
} 
polícia - cujas atividades de caráter criminal e judiciário, por assim dizer, eram desempenhadas àquela altura por juízes de paz, juízes criminais e pelo intendente geral -, estabelecia-se um corpo de cidadãos voluntários, entre 18 e 40 anos, sob uma hierarquia militarizada - a exemplo daquela das tropas do exército e da antiga Guarda Real da Polícia.

Além disso, a nomeação dos integrantes do estado-maior e dos comandantes de companhias era prerrogativa do governo, na Corte; e dos presidentes em conselho, nas províncias. Tratava-se, sobretudo, de cargos de confiança. A lógica, nesse sentido, era parecida com aquela que, em meio à crise de julho, conferiu ao governo a organização das guardas municipais - que até então eram responsabilidade dos juízes de paz nas localidades.

O decreto previa uma espécie de código de conduta para os membros do Corpo, em que eram estabelecidas as penas às quais estavam sujeitos caso faltassem ao cumprimento de seus deveres ou praticassem atos de desobediência, injúria, ameaça ou ofensa física aos superiores, e deserção. Eram regulamentadas, ainda, as punições previstas quando cometidas irregularidades vinculadas à prática de crimes, ou sua tolerância, relacionadas ao emprego; e o uso de armas para realizar ajuntamentos ilícitos.

Em 29 de novembro de 1831, o Ministério da Justiça publicaria uma decisão na qual eram dadas instruções para as rondas dos guardas municipais permanentes. Nas ações de patrulhamento, que deveriam acontecer durante o dia e a noite pela cidade e em seus arredores, as rondas tinham como obrigação prender a qualquer um que estivesse cometendo crime - ou que constasse tê-lo cometido há pouco tempo; prender os indivíduos reunidos em número de três ou mais que dessem "[...] indícios de estarem para cometer algum crime; ou, sendo noite, os que estiverem reunidos em número de cinco ou mais, “[...] sem algum fim justo e reconhecido".

Caberia às rondas observar para que nos ajuntamentos " [...] por causa de algum espetáculo ou qualquer motivo justo" se mantivesse “[...] a ordem e tranquilidade". Em caso de perturbação - ou ao menos indícios dela - cabia- 
lhes dar parte ao juiz de paz mais próximo, fazendo o que a autoridade eletiva lhe ordenasse quando chegasse ao local.

Deveriam prender qualquer indivíduo “[...] doido furioso ou embriagado"; aqueles que trouxessem armas de qualquer natureza, exceto os militares com as de seu uniforme e estando em serviço; os que cometessem "[...] alguma ação evidentemente ofensiva à moral pública e aos bons costumes"; e os que portassem instrumentos de furto ou de crime. Ademais, entre suas atividades, previa-se a necessidade de "[...] apalpar a qualquer pessoa que se fizer suspeita" a fim de verificar a existência de armas ou instrumentos de crime, prendendo-a caso algo do tipo fosse encontrado.

Poderiam entrar em domicílios para prender criminosos durante o dia; e tanto de dia quanto de noite, poderiam adentrar em casa alheia caso lhes fosse solicitado socorro ou se dentro do local estivesse sendo cometida violência contra alguém. E se, por ventura, algum malfeitor se refugiasse em alguma residência durante a noite, deveriam requerer ao dono que o entregasse. Em caso de recusa, deveriam dar parte ao juiz de paz e fazer o que lhes fosse por escrito ordenado.

Em tabernas, lojas, açougues e casas públicas em geral, poderiam entrar para prender criminosos ou dissolver reunião de escravizados. Cabia às rondas, ainda, impedir gritos e vozerias pelas ruas, levando ao juiz de paz os indivíduos que não obedecessem a suas ordens. As prisões, por seu turno, deveriam ser feitas em nome dos juízes de paz, dos juízes criminais ou do intendente da polícia.

No exercício de suas funções, deveriam guardar "[...] aquela civilidade e respeito devido aos direitos do cidadão", sem exceção de pessoa alguma. No entanto, com os que resistissem a suas ações, as rondas estavam autorizadas a aplicar "[...] a força necessária para efetuar-se a diligência". Por fim, deveriam dar parte de todos os acontecimentos aos comandantes de companhia diariamente, com declaração do lugar, hora e testemunhas; caso não houvesse, deveriam chamar "[...] três vizinhos para testemunharem, declarando na parte seus nomes e moradas para serem procuradas pelo juiz". Um extrato com as 
informações das prisões e observações pertinentes sobre tempo e lugar deveria ser reportado ao ministro da justiça no mesmo dia.

\section{Considerações finais}

As medidas adotadas pelo governo regencial tiveram um caráter de suma importância no redesenho do aparato policial no início da década 1830 . Embora o Corpo de Guardas Municipais Permanentes possa ser concebido como um substituto funcional da Guarda Real (HOLLOWAY, 1997), considerando sua função precípua relacionada ao patrulhamento da cidade, há aspectos que merecem maior atenção.

A autorização dada pelo parlamento em 10 de outubro fazia com que um mesmo modelo policial pudesse ser implantado em diferentes regiões do Império. As guardas municipais - que ganhariam, a posteriori, o epíteto "permanentes" - consubstanciaram-se em uma tentativa de colocar a manutenção da ordem nas mãos dos cidadãos para além dos limites da Corte.

Por certo, os legisladores pesaram nessa decisão as dificuldades para o estabelecimento das guardas nacionais nos confins do Brasil naquele período. $\mathrm{O}$ "corpo municipal a soldo", conforme as palavras de Evaristo da Veiga, teria mais chances de êxito; o controle das ruas e da "populaça" era questão que, àquela altura, já colocava inúmeras províncias ao menos em alerta ${ }^{36}$.

Ademais, a caracterização dos Permanentes como meros substitutos dos soldados da Guarda Real encobre a construção liberal acerca da defesa da participação cidadã nas instituições policiais e mantenedoras da ordem. Decerto, as atividades de patrulhamento e ronda pelas ruas e arredores da Corte remontavam às ações empreendidas pela Guarda Real; e, sem dúvida, a

\footnotetext{
${ }^{36}$ Nos anos seguintes, instituições análogas ao Corpo de Guardas Municipais Permanentes da Corte foram criadas em diferentes províncias. O modelo policial criado sob a Regência e o ministério de Diogo Feijó se espalhara pelo Império. Análises sobre a atuação dos Permanentes para além da Corte podem ser encontradas, por exemplo, em: "Entre a liturgia e o salário: a formação dos aparatos policiais no Recife do século XIX (1830-1850)", de Wellington Barbosa da Silva (2003); "Em nome da ordem: a constituição de aparatos policiais no universo lusobrasileiro" (séculos XVIII e XIX)", de Regina Helena Martins de Faria (2007); e "Policiais, pedestres e inspetores de quarteirão: algumas questões sobre as vicissitudes do policiamento na província de Minas Gerais (1831-1850)”, de Ivan de Andrade Vellasco (2007).
} 
permanência da lógica militar na organização da instituição representara um aspecto de suma importância nas suas atividades cotidianas.

Entretanto, é preciso considerar que, durante boa parte do ano 1831, a saída apresentada nos discursos liberais moderados dava conta do estabelecimento de "guardas cidadãs" a fim de assegurar, pelas mãos daqueles que efetivamente tinham interesse na manutenção da segurança e da propriedade, a ordem nas ruas perante os "anarquistas" e a "gente de ínfima condição".

Nesse sentido, em que pese a importância das interpretações que enxergam a adoção do modelo militarizado pelo governo regencial como a única alternativa capaz de manter os membros do Corpo sob controle em um cenário de franca instabilidade das tropas tradicionais, pretende-se conceber que havia outros elementos vinculados a tal escolha. Se a disciplina militar, por si só, fosse capaz de garantir a obediência e a sujeição, não teriam ocorrido a maioria dos levantes de 1831 na capital.

A criação do Corpo de Guardas Municipais Permanentes fora um experimento, uma saída para a encruzilhada que se colocava naquele momento, mas sobremodo alinhada aos postulados liberais moderados. Por algum tempo, a defesa das guardas cidadãs, trabalhando em conjunto com os juízes de paz, dera o tom daquilo que os moderados desejavam para o patrulhamento da cidade: os cidadãos, aqueles que efetivamente tinham algo a perder, os "voluntários da pátria", seriam os membros ideais para integrar as forças responsáveis pela manutenção da ordem. Era o mesmo princípio que legitimava a criação das guardas nacionais.

Entretanto, em meio às inúmeras dificuldades relacionadas à adesão dos cidadãos às guardas de modo a atender às demandas que as circunstâncias impuseram, houve certa acomodação e adaptação à realidade política e social do período. Fora o "espírito militar" que durante o Primeiro Reinado mantivera o Império unido e o controle das ruas na Corte - com as tropas de linha e os soldados da Guarda Real. 
Sob a perspectiva moderada, o governo regencial, “[...] despojado de todo o prestígio da Realeza", era fraco por natureza. Convinha, desse modo, dotá-lo de força “[...] para conservar sua própria independência como poder

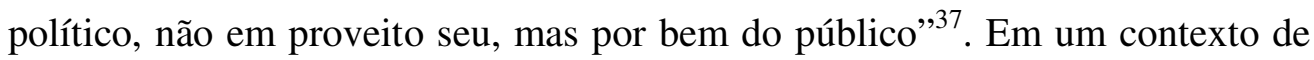
tamanha instabilidade, seria quase impossível desprezar a herança por completo; a turbulência do momento avalizava o estabelecimento dos Permanentes, sobretudo, como o justo meio entre o antigo e o moderno - de fato, a grande bandeira da moderação para todos os temas.

Por um lado, garantia-se que elementos caros aos liberais desde anos anteriores estivessem presentes, como a vinculação do Corpo ao Ministério da Justiça e não ao da Guerra; a ausência dos castigos corporais; a obrigatoriedade da cidadania para o alistamento; e a sujeição à autoridade dos juízes de paz cidadãos eleitos localmente, gozando de amplas atribuições desde a lei de 6 de junho daquele ano.

Por sua vez, considerando os embaraços que se colocaram nos idos daquele ano, afiançava-se a vinculação dos membros à nova instituição, por meio dos soldos; além disso, unia-se a "verdadeira bravura" dos cidadãos livres à "ciência da guerra", sob a hierarquia e a direção dos oficiais militares. Por certo, as ações desempenhadas pelo batalhão dos oficiais nos conflitos daquele período ajudaram a construir tal alternativa; não por acaso, Luís Alves de Lima e Silva, que se destacara à frente do grupo de oficiais, seria nomeado o primeiro comandante do Corpo de Guardas Municipais Permanentes.

Ao final do turbulento ano de 1831, o projeto moderado saíra ganhando: as tropas do exército regular foram reduzidas; a Guarda Real da Polícia estava dissolvida; os juízes de paz gozavam de amplas atribuições, conferidas sobretudo pela lei de 6 de junho; a lei de criação da Guarda Nacional fora aprovada; e o Corpo de Guardas Municipais Permanentes encontrava-se instituído. A despeito dos inúmeros levantes e conflitos ocorridos nos primeiros meses após a abdicação, a reformulação do aparato policial estava quase

\footnotetext{
${ }^{37}$ A Aurora Fluminense, n. 477, de 27 de abril de 1831, p. 2015.
} 
completa. E o governo regencial, sob os moderados, resistia na condução da "nau do Estado".

No ano seguinte, outro grande empreendimento seria levado a cabo - a promulgação do Código de Processo Criminal. Os magistrados eletivos seriam inscritos taxativamente como a principal autoridade no ordenamento policial e judiciário do Império. Não obstante, as medidas adotadas nos primeiros anos da década de 1830 começariam, ainda muito cedo, a encontrar revezes.

Críticas aos juízes de paz no tocante aos mais variados aspectos, desde sua incapacidade jurídica até denúncias de corrupção, seriam frequentes. Por outro lado, no que se vinculava às atividades de patrulhamento, os problemas não foram menores. O reduzido efetivo dos Corpos de Guardas Municipais deixaria para a Guarda Nacional inúmeras dessas ações; os conflitos entre seus membros, magistrados eletivos e guardas municipais permanentes figuraria como tema central em inúmeras decisões ministeriais daquele período.

A mudança na orientação política em finais dos anos de 1830 acabaria por gerar transformações significativas na organização das instituições policiais feita pelos moderados. Já sob o Segundo Reinado, em atendimento ao disposto na lei do orçamento de 1841, um novo regulamento para o Corpo de Guardas Municipais Permanentes fora aprovado pelo Legislativo - o mesmo parlamento que, meses antes, aprovara a reforma do Código de Processo Criminal, em dezembro de 1841.

Ao nível do policiamento das ruas, operava-se uma considerável reformulação. Em verdade, tratava-se de reorganizar o aparato policial não só contando com praças do exército regular, mas também a partir de uma lógica profundamente militarizada no interior do Corpo de Permanentes.

As modificações trazidas pelo regulamento de 1842 seriam responsáveis pela reorganização das forças policiais, conferindo-lhe feições semelhantes àquelas do exército. E que, no limite, a experiência moderada tentara mitigar quando, em 1831, eliminara a Guarda Real da Polícia e, pouco depois, instituíra as guardas municipais, a Guarda Nacional, bem como o Corpo de Guardas Municipais Permanentes. 
Para a força policial da Corte, não coubera a dissolução e a passagem de suas atividades ao exército. Em vez disso, mantivera-se o Corpo, mas sob outros moldes - que remontavam, com as devidas ressalvas, aos tempos da Guarda Real. Os cidadãos voluntários continuariam na instituição, por certo. A vinculação ao Ministério da Justiça também se manteria. Contudo, considerando as queixas acerca do número de membros do Corpo, que figuravam nos discursos desde o início da Regência, seria forçoso crer que as praças de linha não engrossariam significativamente suas fileiras. ${ }^{38}$

As mudanças na dinâmica política empreendidas a partir de 1837 deram o tom das transformações institucionais dos anos seguintes. O aparato policial quer fosse aquele vinculado às rondas e ao patrulhamento das ruas, quer fosse aquele relacionado à investigação e à instrução processual -, não passara incólume. Em meio a disputas e projetos políticos, estava a polícia. E as transformações na organização das instituições policiais, decerto, guardariam estreita relação com o processo de formação do próprio Estado.

A bem da verdade, alguns desses aspectos apresentam ressonâncias até os dias atuais. Não por acaso, os embates em torno da desmilitarização das forças policiais ainda é ponto fulcral nos debates sobre segurança pública; e evidenciam os desafios que as transformações institucionais encotram perante as permanências no Brasil.

\section{Referências}

ABREU, L. Pina Manique: um reformador no Portugal das Luzes. Lisboa: Gradiva, 2013.

ALGRANTI, L. M. O feitor ausente: Estudos sobre a escravidão urbana no Rio de Janeiro (1808-1822). Petrópolis: Vozes, 1988.

ALVARÁ com força de Lei da criação da Intendência Geral da Polícia e seu Regulamento, de 25 de junho de 1760.

\footnotetext{
${ }^{38}$ Em "A polícia carioca no Império “, Marcos Bretas (1998) demonstrara como a composição das forças policiais ao longo das décadas de 1830, 1840 e 1850 fora deficitária. Os pedidos de dispensa, bem como as deserções, seriam uma constante.
} 
ALVARÁ de 15 de janeiro de 1780 - Regulando novamente a jurisdição do Intendente Geral da Polícia.

ALVARÁ de 10 de maio de 1808 - Cria o lugar de Intendente Geral da Polícia da Corte e do Estado do Brasil.

ARAÚJO, C. E. M. de. Entre dois cativeiros: escravidão urbana e sistema prisional no Rio de Janeiro 1790-1821. In: MAIA, Clarissa Nunes; NETO, Flávio de Sá; COSTA, Marcos; BRETAS, Marcos Luiz (Org.). História das prisões no Brasil - Volume I. Online. Disponível em:

$<$ https://www.academia.edu/attachments/50383879/download_file?st=MTU0M DI1MzM2MiwxNzkuMjEwLjE2Mi4yMTEsNjAwNDkxNDA\%3D\&s=swptoolba>. Acesso em: 22 mai. 2018.

ASTRÉA, n. 317, 12 de agosto de 1828, p. 1309.

A AURORA FLUMINENSE, n. 59, de 25 de junho de 1828. A AURORA FLUMINENSE, n. 323, de 10 de abril de 1830. A AURORA FLUMINENSE, n. 462, de 16 de março de 1831. A AURORA FLUMINENSE, n. 471, de 13 de abril de 1831. A AURORA FLUMINENSE, n. 473, n. 18 de abril de 1831. A AURORA FLUMINENSE, n. 477, de 27 de abril de 1831. A AURORA FLUMINENSE, n. 490, de 30 de maio de 1831. A AURORA FLUMINENSE, n. 491, de 1 de junho de 1831. A AURORA FLUMINENSE, n. 492, de 3 de junho de 1831. A AURORA FLUMINENSE, n. 493, de 6 de junho de 1831. A AURORA FLUMINENSE, n. 506, de 11 de julho de 1831. A AURORA FLUMINENSE, n. 513a, de 1 de agosto de 1831. A AURORA FLUMINENSE, n. 521, de 24 de agosto de 1831. A AURORA FLUMINENSE, n. 538, de 3 de outubro de 1831. A AURORA FLUMINENSE, n. 540, de 7 de outubro de 1831. A AURORA FLUMINENSE, n. 545, de 19 de outubro de 1831.

BASILE, M. O. O império em construção: projetos de Brasil e ação política na Corte Regencial. 2004, 490f. Tese (Doutorado em História) - Universidade Federal do Rio de Janeiro, Rio de Janeiro, 2004.

BASILE, M. O. O laboratório da nação: a era regencial (1831-1840). In: GRINBERG, K.; SALLES, R. O Brasil Imperial, Vol. II - 1831-1870. Rio de Janeiro: Civilização Brasileira, 2009, p. 53-119.

BASILE, M. O. Revolta e cidadania na Corte regencial. Tempo, Niteroi, v. 11, n. 22, p. 31-57, 2007.

BRETAS, M. L. A polícia carioca no Império. Estudos históricos, Rio de Janeiro, n. 22, p. 219-234, 1998. 
CAMPOS, A. P.; VELLASCO, I. de A. Juízes de Paz, mobilização e interiorização da política. In: CARVALHO, J. M.; CAMPOS, A. P. Perspectivas da cidadania no Brasil Império. Rio de Janeiro: Civilização Brasileira, 2011, p. 377-408.

CARTA de Lei de 25 de março de 1824 - Manda observar a Constituição Política do Império, oferecida e jurada por Sua Majestade o Imperador.

CASTRO, J. B. de. A milícia cidadã: a Guarda Nacional de 1831 a 1850 . São Paulo: Companhia Editora Nacional, 1977.

COSER, I. Visconde do Uruguai: centralização e federalismo no Brasil, 18231866. Belo Horizonte: Editora UFMG, 2008.

DECISÃO MINISTERIAL - N. 127 - Império - em 4 de junho de 1831 - Declara que os Juízes de Paz estão autorizados para fazerem executar as novas posturas municipais.

DECISÃO MINISTERIAL - N. 129 - Guerra - em 6 de junho de 1831 - Manda publicar as disposições relativas aos ajuntamentos ilícitos, e uso de armas fora do serviço militar.

DECISÃO MINISTERIAL - N. 133 - Justiça - em 8 de junho de 1831 - Censura a má administração da polícia municipal na limpeza e iluminação da Cidade.

DECISÃO MINISTERIAL - N. 135 - Justiça - em 11 de junho de 1831 - Ordena que os marinheiros encontrados em terra depois do sol posto sejam remetidos ao Juiz de Paz para lhe impor a pena das posturas municipais.

DECISÃO MINISTERIAL - N. 152 - Justiça - em 25 de junho de 1831 - Os militares nenhum privilégio têm que os isente de serem presos em flagrante por qualquer cidadão.

DECISÃO MINISTERIAL - N. 178 - Guerra - em 16 de julho de 1831 - Permite que as praças vão servir nos corpos estacionados nas suas Províncias, ou nas que lhes sejam mais próximas.

DECISÃO MINISTERIAL - N. 179 - Guerra - em 16 de julho de 1831 - Manda demitir do serviço as praças que tenham sido violentamente recrutadas.

DECISÃO MINISTERIAL - N. 180 - Guerra - em 16 de julho de 1831 - Proíbe o castigo das chibatadas.

DECISÃO MINISTERIAL - N. 181 - Guerra - em 17 de julho de 1831 - Manda organizar um corpo dos oficiais que ofereceram voluntariamente os seus serviços, para guarnecer algumas repartições e estabelecimentos públicos. 
DECISÃO MINISTERIAL - N. 204 - Justiça - Em 27 de julho de 1831 - Organiza um corpo de tropa regular para auxiliar a justiça.

DECISÃO MINISTERIAL - N. 399 - Justiça - Em 29 de novembro de 1831 Instruções para as rondas municipais permanentes.

DECRETO de 14 de junho de 1831 - Cria em cada distrito de paz um corpo de guardas municipais dividido em esquadras.

DECRETO de 17 de julho de 1831 - Autoriza o Governo para nomear um Comandante geral das guardas municipais do Rio de Janeiro e manda admitir nas mesmas guardas os filhos famílias de pessoas que tenham as qualidades para eleitor.

DECRETO de 22 de outubro de 1831 - Dá regulamento ao Corpo de Guardas Municipais Permanentes da Corte.

FARIA, R. H. M. de. Em nome da ordem: a constituição dos aparatos policiais no universo luso-brasileiro (sécs. XVIII e XIX). 2007, 255f. Tese (Doutorado em História) - Universidade Federal de Pernambuco, Recife, 2007.

FLORY, T. El juez de paz y el jurado en el Brasil imperial. Cidade do México: Fondo de Cultura Económica, 1986.

FOUCAULT, M. Aula de 29 de março de 1978. In: FOUCAULT, M. Segurança, território, população: curso dado no Collége de France (19771978). São Paulo: Martins Fontes, 2008, p. 419-448.

FOUCAULT, M. "Omnes et singulatim": uma crítica da razão política. In: FOUCAULT, M. Ditos e Escritos, Volume IV: Estratégia, Poder-Saber. $3^{\text {a }}$ Edição. Rio de Janeiro: Forense Universitária, 2012, p. 348-378.

GAGLIARDO, V. C. A Intendência de Polícia e a civilização do Rio de Janeiro. Urbana, Campinas, v. 6, n. 8, p. 376-401, set. 2004.

GUERRA, F. X. De la política antígua a la política moderna: algunas proposiciones. Anuario IEHS, Buenos Aires, v. 18, p. 201-212, 2003.

GUERRA, F. X. Modernidad e independências: ensayos sobre las revoluciones hispânicas. Madrid: Editorial Mapfre, 1992.

HOLLOWAY, T. H. O Calabouço e o Aljube no Rio de Janeiro no século XIX. In: MAIA, Clarissa Nunes; NETO, Flávio de Sá; COSTA, Marcos; BRETAS, Marcos Luiz (Org.). História das prisões no Brasil - Volume I. Online. Disponível em: 
<https://www.academia.edu/attachments/50383879/download_file?st=MTU0M DI1MzM2MiwxNzkuMjEwLjE2Mi4yMTEsNjAwNDkxNDA\%3D\&s=swptoolba>. Acesso em: 22 mai. 2018.

HOLlOWAY, T. H. Polícia no Rio de Janeiro: repressão e resistência numa cidade do século XIX. Rio de Janeiro: Fundação Getúlio Vargas, 1997.

LEI de 15 de outubro de 1827 - Cria em cada uma das freguesias e das capelas curadas um Juiz de Paz e um suplente.

LEI de 27 de agosto de 1828 - Dá Regimento para os Conselhos Gerais de Província.

LEI de 1 de outubro de 1828 - Dá nova forma às Câmaras Municipais, marca suas atribuições, e o processo para sua eleição e dos Juízes de Paz.

LEI de 24 de novembro de 1830- Fixa as forças de terra para o ano financeiro de 1831-1832.

LEI de 16 de dezembro de 1830 - Manda executar o Código Criminal do Império.

LEI de 6 de junho de 1831 - Dá providências para a pronta administração e punição dos criminosos.

LEI de 17 de julho de 1831 - Extingue o Corpo da Guarda militar da Polícia do Rio de Janeiro.

LEI de 18 de agosto de 1831 - Cria as Guardas Nacionais e extingue os corpos de milícias, guardas municipais e ordenanças.

LEI de 10 de outubro de 1831 - Autoriza a criação de corpos de guardas municipais voluntários nesta cidade e nas províncias.

LEI de 29 de novembro de 1832 - Promulga o Código do Processo Criminal de primeira instância com disposição provisória acerca da administração civil.

LEI N. 108, de 26 de maio de 1840 - Fixando a Despesa, e orçando a receita para o ano financeiro de 1840-1841.

LEI N. 261, de 3 de dezembro de 1841 - Reformando o Código do Processo Criminal.

LEI N. 191 - Regulamento do $1^{\circ}$ de julho de 1842 - Regula a organização e disciplina da Guarda Municipal Permanente.

LEMOS, N. G. Um Império nos Trópicos: a atuação do Intendente Geral de Polícia, Paulo Fernandes Viana, no Império Luso-Brasileiro. 2012, $130 f$. 
Dissertação (Mestrado em História) - Universidade Federal Fluminense, Niterói, 2012.

LUZ BRASILEIRA, n. 34, de 3 de março de 1830.

MOREL, M. As transformações dos espaços públicos: imprensa, atores políticos e sociabilidades na cidade imperial (1820-1840). São Paulo: Hucitec, 2005 .

NEVES, L. M. B. P.; NEVES, G. P. Constituição. Ler História [online], n. 55, 2008. Disponível em: <http://lerhistoria.revues.org/2203>. Acesso em: 22 mar. 2017.

NOVA LUZ BRASILEIRA, n. 129, de 25 de março de 1831.

NOVA LUZ BRASILEIRA, n. 169, de 10 de setembro de 1831.

NOVA LUZ BRASILEIRA, n. 176, de 29 de setembro de 1831.

O REPÚBLICO, n. 59, de 28 de abril de 1831.

O VERDADEIRO LIBERAL, n. 9, de 21 de março de 1826.

SALDANHA, F. H. D. Os oficiais do povo: a Guarda Nacional em Minas Gerais oitocentista (1831-1850). São Paulo: Annablumme, 2006.

SALDANHA, F. H. D. O império da ordem: Guarda Nacional, coronéis e burocratas em Minas Gerais na segunda metade do século XIX (1850-1873). São Paulo: Unesp, 2013.

SCHIERA, P. A "polícia" como síntese de ordem e bem-estar no moderno Estado centralizado. In: HESPANHA, A. M. (Org.). Poder e instituições na Europa do Antigo Regime: Colectânea de textos. Lisboa: Fundação Calouste Gulbenkian, 1984, p. 307-319.

SEELAENDER, A. C. L. A "polícia” e as funções do Estado: notas sobre a "polícia" do Antigo Regime. Revista da Faculdade de Direito, Curitiba, v. 49, p.73-89, 2009.

SEELAENDER, A. C. L. A polícia e o rei-legislador. Notas sobre algumas tendências da legislação portuguesa no Antigo Regime. In: BITTAR, E. C. B. História do direito brasileiro: leituras da ordem jurídica nacional. $2^{\mathrm{a}}$ Ed. São Paulo: Editora Atlas, 2010, p. 120-135.

SILVA, M. B. N. A Intendência-Geral da Polícia: 1808-1821. Acervo, Rio de Janeiro, v. 1, n. 2, p. 187-204, jul.-dez. 1986. 
SILVA, W. B. da. Entre a liturgia e o salário: a formação dos aparatos policiais no Recife do século XIX (1830-1850). 2003. 281f. Tese (Doutorado em História) - Universidade Federal de Pernambuco, Recife, 2003.

SLEMIAN, A. Sob o império das leis: Constituição e unidade nacional na formação do Brasil (1822-1834). 2006, 338f. Tese (Doutorado em História) Universidade de São Paulo, São Paulo, 2006.

SOARES, J. de S. A polícia oitocentista entre a inovação e a tradição. 2019, 398f. Tese (Doutorado em História) - Universidade Federal do Estado do Rio de Janeiro, Rio de Janeiro, 2019.

SOARES, J. de S. Polícia e juízes de paz na imprensa oitocentista (1826-1829). Passagens: Revista Internacional de História Política e Cultura Jurídica, Rio de Janeiro, v. 9, n. 3, p. 416-445, set./dez. 2017.

SUBTIL, J. M. L. L. O direito de polícia nas vésperas do Estado liberal em Portugal. In: FONSECA, R. M. As formas do direito: ordem, razão e decisão. Curitiba: Juruá Editora, 2013, p. 275-332.

VELLASCO, I. de A. As seduções da ordem: violência, criminalidade e administração da justiça, Minas Gerais, século 19. Bauru: EDUSC, 2004.

VELLASCO, I. de A. Policiais, pedestres e inspetores de quarteirão: algumas questões sobre as vicissitudes do policiamento na província de Minas Gerais (1831-1850). In: CARVALHO, J. M. de (Org.). Nação e Cidadania no Império: novos horizontes. Rio de Janeiro: Civilização Brasileira, 2007, p. 237265.

ZULli, A. L. C. A. Guarda Real da Polícia do Rio de Janeiro: um estudo sobre as atribuições da primeira instituição policial ostensiva brasileira (18091831). 2018, 150f. Dissertação (Mestrado em História) - Universidade Federal do Estado do Rio de Janeiro, Rio de Janeiro, 2018.

Recebido em: 25 de setembro de 2019 Aceito em: 20 de abril de 2020 